\author{
Asian Journal of \\ Medical and Biological Research \\ ISSN 2411-4472 (Print) 2412-5571 (Online) \\ www.ebupress.com/journal/ajmbr
}

\title{
Article \\ Feeding effect of total mixed ration on milk yield, nutrient intake, digestibility and rumen environment in Red Chittagong Cows
}

\author{
Nathu Ram Sarker ${ }^{1,2}$, Dilruba Yeasmin ${ }^{2}$, Md Ahsan Habib ${ }^{2 *}$ and Farah Tabassum ${ }^{2}$ \\ ${ }^{1}$ Poultry Production Research Division, Bangladesh Livestock Research Institute (BLRI), Savar, Dhaka, \\ Bangladesh \\ ${ }^{2}$ Fodder Research and Development Project, Bangladesh Livestock Research Institute (BLRI), Savar, Dhaka, \\ Bangladesh
}

*Corresponding author: Md. Ahsan Habib, Fodder Research and Development Project, Bangladesh Livestock Research Institute (BLRI), Savar, Dhaka, Bangladesh. Phone: +8801712855030; E-mail: ahsan.rony@yahoo.com

Received: 05 March 2019/Accepted: 27 March 2019/ Published: 31 March 2019

\begin{abstract}
Efficient utilization of crop residues is an alternative way to overcome feed shortage for livestock feeding. Hence, an experiment was conducted to determine the effect on nutrient intake, milk yield, nutrient digestibility and rumen parameters of total mixed ration (TMR) as mash or block form in comparison to conventional feeding system for a period of 45 days. Accoding to CRD 18 RCC early milking cows (Bos indicus) having average daily milk yield of $3.20 \pm 0.14 \mathrm{~L} / \mathrm{d}$ and divided into three treatment groups. Existing feeding practice at the farm was considered as control group $\left(\mathrm{T}_{0}\right)$ fed Napier-3 adlib. and concentrate mixture. In another two groups, animals fed TMR, where one fed as block $\left(T_{1}\right)$ and another as mash form $\left(T_{2}\right)$ with the same roughage and concentrate combination (50:50). All diets contained 16\% CP. To determine digestibility of supplied feed, a digestibility trial at the middle of the feeding trial was conducted and also to study the rumen environment ( $\mathrm{pH}, \mathrm{TVFA}, \mathrm{NH}_{3}-\mathrm{N}$ ), rumen liquors were collected at post feeding intervals of 3, 6, 12, 24 and 36h. Study revealed that fresh feed intakes were significantly $(\mathrm{p}<0.001)$ higher in $\mathrm{T}_{0}$. DMI and CPI were significantly $(\mathrm{p}<0.001)$ higher in $\mathrm{T}_{1}$ group. Significantly $(\mathrm{p}<0.05)$ highest milk yields were obtained in $\mathrm{T}_{1}(3.6 \mathrm{l} / \mathrm{d})$ and $\mathrm{T}_{2}$ $(3.49 \mathrm{l} / \mathrm{d})$ and lowest in $\mathrm{T}_{0}(3.351 / \mathrm{d})$. Milk fat $(\mathrm{p}<0.001)$ and $\mathrm{SNF}(\mathrm{p}<0.05)$ were significantly higher $\mathrm{T}_{1}$ and $\mathrm{T}_{2}$. Except ADF, digestibility for most of the nutrient was significantly higher in $T_{1}$ and $T_{2}$ than $T_{0}$. Total volatile fatty acids (TVFA) and ammonia-nitrogen $\left(\mathrm{NH}_{3}-\mathrm{N}\right)$ were significantly $(\mathrm{p}<0.01)$ higher in $\mathrm{T}_{1}$ and $\mathrm{T}_{2}$ groups than that of $\mathrm{T}_{0}$ group. Finally, it may be concluded that TMR, either in block or mash form gives better results in terms of milk yield, milk composition, digestibility and concentration of TVFA and $\mathrm{NH}_{3}-\mathrm{N}$.
\end{abstract}

Keywords: densified TMR; crop residues; nutrient digestibility; rumen environment; milk yield; milk composition

\section{Introduction}

A major constraint to livestock production in Bangladesh is the scarcity and fluctuating quantity and quality of the year-round feed supply. Due to cultivation of food and commercial crops, enormous quantities of different types of crop residues are produced as a renewable resource every year. The conventional feeding systems in Bangladesh for bovine consist of feeding roughage and concentrate separately at different time intervals. Selective consumption of feeds is more in this type of feeding system which leads to a great loss of feeds as for wastages and improper nutrient utilization. Besides, the rumen environment of the ruminants change with the ingestion of feed stuffs which in turn affect the ruminal digestion, nutrient absorption and rate of passage. In conventional feeding system, animals consume a high proportion of concentrates which increase the risk of ruminal acidosis (Maekawa et al., 2002). Total mixed ration (TMR) is a revolutionary concept in the feeding 
and delivering the nutrients to the bovines. TMR is the best way for balancing the feed for the animals and improve the nutrient utilization, resulting in optimum productive and reproductive performance of the animals. TMR diets have often been attributed to a ruminal steady state condition, stabilize rumen fermentation pattern and improve energy and protein utilization in the rumen (Coppock et al., 1981). The merits of total mixed ration are related to the enhancement of utilization of low grade roughages, provides uniform feed intake, and reduces feed wastage, a stable environment for rumen fermentation, minimal fermentation losses and fluctuation in release of ammonia (Rao et al., 2014). Among various available feed resources, maize (Zea mays) cob can be considered to be one of the important potential crop residues available for ruminants feeding in country. The major residues obtained from this crop are maize husk, stover and which may be used as alternative feed resources for ruminants, especially during dry season. This study was conducted to know the effect of maize stover based TMR on nutrient intake, milk yield, milk composition, nutrient utilization and rumen environment on Red Chittagong cows.

\section{Materials and Methods}

\subsection{Location and duration of experiment}

This experiment was conducted at Bangladesh Livestock Research Institute (BLRI), Savar, Dhaka for a period of 45 days from $23^{\text {rd }}$ June to $6^{\text {th }}$ August, 2017.

\subsection{Experimental design and chemical composition of feed}

According to CRD, eighteen early lactating Red Chittagong Cattle (RCC) cows having initial average body weight of $265 \pm 10.87 \mathrm{~kg}$ and $4.5 \%$ FCM yielded daily average of $3.20 \pm 0.14 \mathrm{~L}$ milk were selected and divided randomly into three treatment groups having six cows in each. Existing feeding practice at the farm was considered as control group $\left(\mathrm{T}_{0}\right)$. In another two groups, animals fed TMR (50\% roughages: $50 \%$ concentrate), where one fed as block $\left(\mathrm{T}_{1}\right)$ and another as mash form $\left(\mathrm{T}_{2}\right)$ with the same combination of roughage and concentrate. All diets contained 16\% CP (Table 1) The animals in control group were offered a conventional ration comprising of $22.0 \mathrm{~kg}$ Napier Hybrid green grass and $3.0 \mathrm{~kg}$ concentrate mixture while the animals in treatment groups were fed TMR comprising of chopped maize stover and concentrate in 50:50 proportions according to their nutrient requirements. The dry matter (DM), crude protein $(\mathrm{CP})$, organic matter $(\mathrm{OM})$, neutral detergent fibre (NDF), acid detergent fibre (ADF), and ash contents were 90.21,16.9, 91.01, 55.55, 23.11 and 12.67 percent, respectively in the concentrate mixture of $\mathrm{T}_{0}, 42.88,15.59,81.4,45.54,45.41$ and 18.6 percent, respectively in $\mathrm{T}_{1}$ and $43.01, .88,15.64,80.17,54.88,45.54$ and 19.83 percent, respectively in $\mathrm{T}_{2}$.All the experimental animals were stall fed with zero grazing. Always fresh, clean and safe drinking water was supplied to the animals.

Table 1. Nutrient and dietary composition.

\begin{tabular}{|c|c|c|c|c|c|}
\hline Feed Ingredient & DM\% & CP\% & $\begin{array}{l}\text { Amount in } \\
100 \mathrm{~kg}\left(\mathrm{~T}_{0}\right)\end{array}$ & $\begin{array}{l}\text { Amount in } 100 \\
\operatorname{kg}\left(T_{1}\right)\end{array}$ & $\begin{array}{l}\text { Amount in } 100 \\
\mathrm{~kg}\left(\mathrm{~T}_{2}\right)\end{array}$ \\
\hline BLRI Napier-3 & 20.39 & 9.4 & 70 & - & - \\
\hline Maize stover & 88.96 & 5.72 & - & 50 & 50 \\
\hline Wheat bran & 87.43 & 15.06 & 5 & 8 & 8 \\
\hline Kheshari bran & 86.55 & 12.22 & 5 & 4 & 4 \\
\hline Soybean meal & 85.78 & 44.13 & 17 & 25 & 25 \\
\hline Molasses & 80.19 & 5.2 & - & 10 & 10 \\
\hline Salt & 99.50 & - & 0.5 & 0.5 & 0.5 \\
\hline DCP & 98.01 & - & 2.5 & 2.5 & 2.5 \\
\hline $\operatorname{DM}(\%$ Fresh basis $)$ in diet & - & - & 40.55 & 42.88 & 43.01 \\
\hline $\mathrm{CP}(\%)$ in diet & - & - & 15.45 & 15.59 & 15.64 \\
\hline ME req.(MJ/Day/Animal) & & & 45.55 & 44.78 & 44.11 \\
\hline ME supp.(MJ/Day/Animal) & & & 48.47 & 48.23 & 48.30 \\
\hline \multicolumn{6}{|l|}{ \%DM Basis } \\
\hline & $\mathrm{OM}$ & Ash & ADF & \multicolumn{2}{|c|}{ NDF } \\
\hline BLRI Napier-3 & 89.13 & 10.87 & 47.77 & \multicolumn{2}{|c|}{68.42} \\
\hline Concentrate mixture of $\mathrm{T}_{0}$ & 91.01 & 12.67 & 23.11 & \multicolumn{2}{|c|}{55.55} \\
\hline $\mathrm{T}_{1}$ & 81.4 & 18.6 & 45.41 & \multicolumn{2}{|c|}{45.54} \\
\hline $\mathrm{T}_{2}$ & 80.17 & 19.83 & 45.54 & \multicolumn{2}{|c|}{54.88} \\
\hline
\end{tabular}

DM- Dry matter; CP- Crude protein; ME- Metabolisable energy; MJ- Mega Joule DCP- Di calcium phosphate 


\subsection{Digestibility trial}

In order to determine digestibility of supplied feed, a conventional digestibility trial at the middle of the feeding trial was conducted having 7 days collection periods. During that period, daily feed intake, feces and urine voided were recorded and collected individually. At the end of the collection period the feces were composites together and then proximate components of each of the samples were analyzed in Animal Nutrition Laboratory at BLRI.

\subsection{Chemical analysis}

The feed samples, leftover and faeces were analyzed by the method of (AOAC, 2007) for determination of DM, CP, OM and Ash, while, ADF and NDF by (Van Soest et al., 1991). All the samples were analyzed in duplicate and mean values were recorded. Milk samples were collected from each cow at 7 days interval and were analyzed for fat, protein, lactose and SNF contents by milk analyzer (Lactostar, Funk Gurbar).

\subsection{Rumen liquor collection}

At the end of the trial, rumen liquor was collected at the intervals of 3, 6, 12, 24 and 36 hours after feeding by using stomach tube having $0.15 \mathrm{~mm}$ internal diameter and $150 \mathrm{~cm}$ long plastic tube. The stomach tube was moistened and animal's mouth was opened by placing thumb in the region without teeth. The tube was then passed over the back of tongue and enters into the esophagus. A vacuum pump was used to apply suction to draw ruminal fluid. The fluid was obtained by lowering the animals head until fluid runs from the tube. Approximately, $150 \mathrm{ml}$ of rumen liquor was collected from two animals in each group. The sucked fluid was filtered by a cheese cloth. The $\mathrm{p}^{\mathrm{H}}$ was measured immediately after collection, using the digital $\mathrm{P}^{\mathrm{H}}$ meter. Then, samples were stored at $-18{ }^{\circ} \mathrm{C}$ for subsequent laboratory analysis. Total volatile fatty acids (TVFAs), ammonia nitrogen $\left(\mathrm{NH}_{3}-\mathrm{N}\right)$ were also measured from the samples collected from those hours.

\subsection{Statistical analysis}

The data were analyzed using the SPSS 17.0 statistical program. Duncan's Multiple Range Test (DMRT) was also done to compare the treatment means for different parameters.

\section{Results}

\subsection{Feed intake and nutrient digestibility}

Fresh feed intake in $\mathrm{T}_{0}$ was significantly higher (Table 1). Results also show that $\mathrm{T}_{1}$ significantly increased total DM and CP intake. CP intake differed significantly ( $\mathrm{p}<0.001)$ among animals of different treatment groups. Highest CP intake was observed in animals of $\mathrm{T}_{1}$ group fed TMR block. Though, animals of all treatment groups were supplied diet containing same \% of $\mathrm{CP}$, but variation of $\mathrm{CP}$ intake could be due to variation of DM intake from diet. Digestibility of proximate components and fiber fractions in feed supplied to animals of different groups are also presented here (Table 2) which shows to have significant differences of DM, CP, OM, (p<0.01) and ash and NDF $(\mathrm{p}<0.001)$ digestibility among treatment groups. In all cases, digestibility of the said components in supplied feed was significantly higher in $\mathrm{T}_{1}$ except those of ash and NDF digestibility, obtained higher in $\mathrm{T}_{2}$. On the other hand, ADF digestibility did not differ significantly among different treatment groups. However, the differences of nutrients digestibility between $T_{1}$ and $T_{2}$ were not significant.

Table 2. Feed intake and nutrient digestibility for different treatment group.

\begin{tabular}{|c|c|c|c|c|}
\hline Parameter & $\mathbf{T}_{\mathbf{0}}$ & $\mathbf{T}_{1}$ & $\mathbf{T}_{2}$ & Significance level \\
\hline \multicolumn{5}{|c|}{ Feed Intake (kg/day) } \\
\hline Fresh feed intake & $24.93^{\mathrm{a}} \pm 0.008$ & $14.40^{\mathrm{b}} \pm 0.02$ & $14.01^{\mathrm{c}} \pm 0.08$ & $* * *$ \\
\hline \multicolumn{5}{|c|}{ Nutrient Intake (kg/day) } \\
\hline DMI & $4.49^{c} \pm 0.001$ & $5.07^{\mathrm{a}} \pm .007$ & $4.91^{\mathrm{b}} \pm .0 .02$ & $* * *$ \\
\hline CPI & $0.72^{c} \pm 0.00$ & $0.8^{\mathrm{a}} \pm 0.00$ & $0.78^{\mathrm{b}} \pm .004$ & $* * *$ \\
\hline DMI on $\%$ live $w t$ & $1.97 \pm 0.22$ & $2.44 \pm 0.39$ & $2.16 \pm 0.15$ & NS \\
\hline \multicolumn{5}{|c|}{ Nutrient Digestibility (\%) } \\
\hline $\mathrm{DM}$ & $53.45^{\mathrm{b}} \pm 1.98$ & $64.60^{\mathrm{a}} \pm 1.14$ & $61.46^{\mathrm{a}} \pm 2.11$ & $* *$ \\
\hline $\mathrm{CP}$ & $66.28^{\mathrm{b}} \pm 2.19$ & $76.46^{\mathrm{a}} \pm .9867$ & $72.83^{\mathrm{a}} \pm 1.96$ & $* *$ \\
\hline $\mathrm{OM}$ & $55.55^{\mathrm{b}} \pm 1.83$ & $66.09^{\mathrm{a}} \pm 1.12$ & $61.4^{\mathrm{a}} \pm 2.22$ & $* *$ \\
\hline Ash & $38.94^{\mathrm{b}} \pm 3.59$ & $58.06^{\mathrm{a}} \pm 2.04$ & $61.4^{\mathrm{a}} \pm 2.22$ & $* * *$ \\
\hline $\mathrm{ADF}$ & $63.45 \pm 2.92$ & $69.3 \pm 1.77$ & $67.94 \pm 2.57$ & NS \\
\hline NDF & $52.38^{\mathrm{b}} \pm 1.58$ & $56.77^{\mathrm{b}} \pm 1.29$ & $64.98^{\mathrm{a}} \pm 1.99$ & $* * *$ \\
\hline
\end{tabular}

DMI-Dry matter intake; CPI- Crude protein intake, LW-Live weight of animal; NS-non significant $(\mathrm{p}>0.05), * * *-p<0.001$ means with uncommon superscript within the same row differed significantly $(\mathrm{p}<0.01)$. 
3.2. Milk yield and composition

Result shows that significant differences $(\mathrm{p}<0.01)$ were found in milk production among treatment groups (Table 3 ). Highest average daily milk yield was observed in $\mathrm{T}_{1}$ group and lowest in $\mathrm{T}_{0}$ group, although there was no significant difference between $T_{1}$ and $T_{2}$ and between $T_{0}$ and $T_{2}$ groups. Fat and SNF contents were significantly different in all treatment groups. On the other hand, protein and lactose contents in milk for different treatment groups did not varied significantly. Apparently, highest milk fat was observed in $\mathrm{T}_{2}$ group, although it did differ with $\mathrm{T}_{1}$. However, milk fat contents in $\mathrm{T}_{1}$ and $\mathrm{T}_{2}$ groups were significantly higher than $\mathrm{T}_{0}$.

Table 3. Milk yield and milk composition of different treatment groups.

\begin{tabular}{lllll}
\hline Parameter & $\mathbf{T}_{\mathbf{0}}$ & $\mathbf{T}_{\mathbf{1}}$ & $\mathbf{T}_{\mathbf{2}}$ & Significance level \\
\hline $\mathbf{4 . 5 \%}$ FCMY & & & & \\
Initial (ltr) & $3.20 \pm 0.14$ & $3.20 \pm 0.14$ & $3.20 \pm 0.14$ & $\mathrm{NS}$ \\
Final (ltr) & $3.35 \pm 0.10$ & $3.60 \pm 0.05$ & $3.49 \pm 0.04$ & $*$ \\
Milk Composition (\%) & & & & \\
Fat & $4.70^{\mathrm{b}} \pm 0.1$ & $5.26^{\mathrm{a}} \pm 0.14$ & $5.28^{\mathrm{a}} \pm 0.08$ & $* * *$ \\
Protein & $3.92 \pm 0.04$ & $4.06 \pm 0.05$ & $4.05 \pm 0.07$ & $\mathrm{NS}$ \\
Lactose & $5.65 \pm 0.05$ & $5.77 \pm 0.06$ & $5.72 \pm 0.07$ & $\mathrm{NS}$ \\
SNF & $10.27^{\mathrm{b}} \pm 0.20$ & $10.78^{\mathrm{a}} \pm 0.07$ & $10.74^{\mathrm{a}} \pm 0.07$ & $*$ \\
\hline
\end{tabular}

NS-non significant $(\mathrm{p}>0.05) ; * *-\mathrm{p}<0.01$; means with uncommon superscript within the same row differed significantly $(\mathrm{p}<0.01)[\mathrm{FCM}=0.4 \times$ Milk yield $+(15 \times$ milk fat in $\mathrm{kg}]$.

\subsection{Metabolic profile in cow}

Rumen environment and fermented substrates for different diets in different post feeding periods are illustrated in Table 4. The result shows that rumen $\mathrm{p}^{\mathrm{H}}$ had no significant differences $(\mathrm{p}>0.05)$ in different hour of fermentation in different treatment groups. Significant differences of TVFA for different diets were observed in different post feeding periods $(0,3,6,12,24$ and 36h). The concentration of TVFA was increasing after $3 \mathrm{~h}$ post feeding, reached a maximum level at $12 \mathrm{~h}$ and then reduced at $24 \mathrm{~h}$ and increasing thereafter. $\mathrm{NH}_{3}-\mathrm{N}$ concentrations differed significantly $(\mathrm{p}<0.05)$ for diets in different periods of fermentation. The changes of $\mathrm{NH}_{3^{-}}$ $\mathrm{N}$ concentrations in different treatment groups were found to be decreased gradually towards $12 \mathrm{~h}$ post feeding, but again increased and reached a maximum level at $24 \mathrm{~h}$ and decreased thereafter.

Table 4. Rumen fermentation parameters in different treatment groups according to different hours.

\begin{tabular}{|c|c|c|c|c|c|c|}
\hline \multirow[t]{2}{*}{ Parameters } & \multirow[t]{2}{*}{ digestion (hour) } & \multicolumn{4}{|c|}{ Dietary treatments } & \multirow[t]{2}{*}{ Level of Significance } \\
\hline & & $\mathbf{T}_{\mathbf{0}}$ & $\mathbf{T}_{1}$ & $\mathbf{T}_{2}$ & SEM & \\
\hline \multirow[t]{5}{*}{$\mathrm{P}^{\mathrm{H}}$} & 3 & 6.64 & 6.36 & 6.45 & 2.64 & NS \\
\hline & 6 & 5.51 & 5.40 & 5.54 & 2.64 & NS \\
\hline & 12 & 6.36 & 6.3 & 6.41 & 2.65 & NS \\
\hline & 24 & 6.57 & 6.56 & 6.54 & 2.67 & NS \\
\hline & 36 & 6.51 & 6.67 & 6.59 & 2.68 & NS \\
\hline \multirow{5}{*}{ TVFA (mM/100 ml) } & 3 & 9.6 & 11.31 & 9.19 & 5.98 & $* *$ \\
\hline & 6 & 10.5 & 12.5 & 11.52 & 4.56 & $* *$ \\
\hline & 12 & 16.2 & 18.8 & 17.43 & 6.80 & $* *$ \\
\hline & 24 & 13.0 & 13.9 & 15.5 & 4.69 & $* *$ \\
\hline & 36 & 15.5 & 19.5 & 18.5 & 6.87 & $* *$ \\
\hline \multirow[t]{5}{*}{$\mathrm{NH}_{3}-\mathrm{N}(\mathrm{g} / 100 \mathrm{ml})$} & 3 & 14.9 & 15.1 & 13.8 & 5.53 & $*$ \\
\hline & 6 & 11.6 & 12.6 & 11.7 & 4.53 & $*$ \\
\hline & 12 & 9.36 & 10.7 & 9.80 & 3.84 & $*$ \\
\hline & 24 & 17.01 & 21.64 & 22.90 & 8.86 & $*$ \\
\hline & 36 & 11.05 & 14.15 & 11.73 & 3.66 & $*$ \\
\hline
\end{tabular}

$*_{*}^{*}$ - $<<0.01,{ }^{*}-\mathrm{p}<0.05$ NS-non significant $(\mathrm{p}>0.05)$; means with uncommon superscript within the same row differed significantly $(\mathrm{p}<0.01)$.

\section{Discussion}

DM and CP intakes were significantly higher in $\mathrm{T}_{1}$ which agreed well with (Lailer et al., 2010; Sehgal and Jha, 2008). They stated that $T_{1}$ significantly improves DM intake. This results also corroborated with the findings of 
(Verma et al., 1996; Sharma et al., 2010; Bargo et al., 2002). (Kolver et al., 1998) compared the nutrients intake in high producing Holstein cows consuming pasture or TMR and found that dry matter intake in grazing cows was lower than that of cows fed on TMR which coincided by our study. In another experiment, (Pandya et al., 2005) studied on the performances of crossbred heifers with wheat straw based complete feed and found higher DM intake in all TMR groups over the conventional system of feeding. They indicated that palatability and small particle sizes of total mixed rations resulted in increased DM intake. Devries and Gill (2012) also observed increased DM intake from molasses-based liquid TMR in lactating cows. This results are in accordance with Chander (2011) and Khan et al. (2010) as they reported that the feeding of total mixed ration in the form of pellets increased the dry matter and CP intake as compared to conventional feeding system (feeding roughage and concentrate separately). Pachauri et al. (2010) observed that wheat straw based total mixed ration and urea ammoniated based total mixed ration increased the dry matter, DCP intake as compared to feeding of wheat straw and concentrate fed separately (conventional feeding) which also conforms to this study. Sharma $e t$ al. (2010) conducted to discern the effect of feeding complete ration as mash or block form in comparison to conventional feeding system on feed intake, growth, nutrient utilization in growing crossbred female calves for a period of 90 days and observed DM/kg W ${ }^{0.75}$ and DCP intake $\left(\mathrm{g} / \mathrm{kg} \mathrm{W}^{0.75}\right)$ to be significantly higher in mash group in comparison to conventional feeding system and also with complete feed in block form. Their results partially contradict with our study which could be due to different genotype, environment or feed ingredients in TMR. Milk production of cows fed TMR was significantly higher than cows of conventional feeding. This result is coincided with the findings of Lailer et al. (2010). The result also agreed with Walli (2015) who conducted an experiment with straw based densified TMR block and got a positive effect on milk production. Bargo et al. (2002) studied performance of milking cows feeding with three different diets viz. pasture plus concentrate, pasture plus partial TMR and TMR (non-pasture) and found significant difference on milk yield and highest milk yield observed in fed only TMR. This findings also imitating with the study of O'Neil et al. (2011) who concluded that cows offered TMR had higher milk yield, solids-corrected milk yield, as compared to those fed ryegrass. Hundal et al. (2004) conducted an experiment with densified TMR block and found no significant changes for milk yield which is contradicted with this study. This contradiction may be due to difference of breed, formulation of feed, feed ingredients, stage of lactation, environment etc. Fat and SNF contents in milk of cows fed TMR were significantly higher than cows fed conventional feeding. This finding agreed well with the Bargo et al. (2002) and White et al. (2001) who reported that cows fed on TMR had higher total milk fat percentage than those grazed on pasture. Gaafer et al. (2011) observed that the milk fat, lactose, SNF and total solids were highest in cow fed with TMR which corresponds with this study. Our results also coincided with the findings of O'Neil et al. (2011) who concluded that cows offered TMR had higher fat and protein yield as compared to those fed ryegrass. It is evident that there are lots of genetic and non-genetic factors responsible for variability of milk composition like breed, heredity, dietary regime, time and frequency of milking, season etc. Konka et al. (2015) conducted an experiment with three different crop residues based complete rations (crop residue and concentrate with ratio of 60:40 in buffalo at India) and found significant difference of in vitro DM digestibility. This result was also similar with the findings of Lailer et al. (2010) and Sehgal and Jha (2008) who described that densified TMR block significantly improves DM digestibility. Shojaeian and Thakur (2007) reported that the increase DM digestibility appeared to be associated with higher NDF digestibility which confirms by this study. Hundal et al. (2004) observed that the digestibility of organic matter and neutral detergent fibre was higher $(\mathrm{P} \leq 0.05)$ in the animals fed with TMR as compared to conventional feeding system which is coincided with this study. Williams and Christian (1959) reported no corresponding changes in rumen $\mathrm{p}^{\mathrm{H}}$ value in different treatment groups. The results of total volatile fatty acids (TVFA) as obtained in present study are highly corrugated with the findings of Reid et al. (1957). The concentration level of TVFA depends on ruminal microbial activity, hydrolysis of protein and NPN (Venkanna et al., 1997). TVFA production is an indicator of carbohydrate digestion especially the crude fiber (Girdhar and Balaraman, 2005). The changes of $\mathrm{NH}_{3}-\mathrm{N}$ concentrations in different treatment groups were found to be decreased gradually towards $12 \mathrm{~h}$ post feeding, but again increased and reached a maximum level at $24 \mathrm{~h}$ and decreased thereafter. According to Carvalho et al. (1997) the reduction in ruminal $\mathrm{NH}_{3}-\mathrm{N}$ concentration can be explained by the increase in energy availability in the rumen, allowing higher use of ammonia for microbial growth, with consequent reduction in ammonia loss due to synchronization in the carbohydrates and protein degradation. 


\section{Conclusions}

Maize stover is a potential crop residue which may be used as an alternative roughage source for livestock feeding during scarcity period. Based on the findings of this study, it may be concluded that, Maize stover based total mixed ration (50:50) can be substituted for conventional feeding as a diet for milking cow.

\section{Acknowledgements}

The authors are so much grateful to Fodder Research and Development Project of Bangladesh Livestock Research Institute for giving fund to conduct this research.

\section{Conflict of interest}

None to declare.

\section{Reference}

AOAC, 2007. Official methods of Analysis, 18th edn. Association of Official Analytical chemists, Washington DC, USA.

Bargo F, LD Muller, JE Delahoy and TW Cassidy, 2002. Performance of high producing dairy cows with three different feeding systems combining pasture and total mixed rations. J. Dairy Sci., 85: 2960-2975.

Carvalho AS, 1997. Ammonia nitrogen determination in plant material. Netherlands J. Agri., 22:3-5.

Coppock CE, DL Bath and B Harris Jr, 1981. From feeding to feeding systems. J. Dairy Sci., 64: 1230-1249.

Chander M, 2011. Chaff cutters and fodder chaffing: A simple technology worth adoption. In H.P.S. Makkar, ed. Proceedings of FAO E- Conference on, Successes and failures with animal nutrition practices and technologies in developing countries. pp. 133-136.

DeVries TJ and RM Gill, 2012. Adding liquid feed to a total mixed ration reduces feed sorting behavior and improves productivity of lactating dairy cows. J. Dairy Sci., 95: 2648-2655.

Gaafer MA, MA Hamed, A Halim, ED Mohi, FA Kotob, EL Reidy and IM Bassiouni, 2011. Productive and reproductive performances of lactating cows and buffaloes fed Total mixed ration. Philipp. J. Vet. Anim. Sci., 37: 131-142.

Girdhar N and N Balaraman, 2005. Feeding of maize fodder based total mixed ration having different levels of energy and protein to lactating crossbred cows. Indian J. Dairy Sci., 61: 435-440.

Hundal JS, RP Gupta, M Wadhwa and MPS Bakshi, 2004. Effect of feeding total mixed ration on the productive performance of dairy cattle. Anim. Nutr. Feed Technol., 4: 179-186.

Khan SR, SK Singh and V Mudgal, 2010. Effect of feeding complete rations on the performance of lactating crossbred cow. Ind. J. Anim. Nutr., 27: 261-264.

Kolver ES and LD Muller, 1998. Performance and nutrient intake of high producing Holstein cows consuming pasture or a total mixed ration. J. Dairy Sci., 81:1403-1411.

Konka RK, SK Dhullipalla, VR Jampala, R Arunachalam, EP Pagdala and RR Elinen, 2015. Evaluation of crop residue based complete rations through in vitro digestibility. J. Adv. Vet. Anim. Res., 2: 64-68.

Lailer PC, SS Dahiya, L Madan and D Lal, 2010. Effect of complete feed blocks on growth performance of Murrah male calves. Indian J. Anim. Nutr., 27: 220-223.

Maekawa M, KA Beauchemin and DA Christensen, 2002. Effect of concentrates level and feeding management on chewing activities, saliva production and ruminal $\mathrm{pH}$ of lactating dairy cows. J. Dairy Sci., 85: 1165 1175.

O'Neil BF, MH Deighton, BM O'Loughlin, FJ Mulligan, TM Boland, M O'Donovan and E Lewis, 2011. Effects of a perennial ryegrass diet or total mixed ration diet offered to spring-calving Holstein-Friesian dairy cows on methane emissions, dry matter intake, and milk production. J. Dairy Sci., 94: 1941-51.

Pachauri SK, SK Singh and V Mudgal, 2010. Effect of Feeding Wheat straw and urea ammoniated wheat straw based total mixed rations on the performance of female crossbred calves. Ind. J. Anim. Nutr., 27: 73-76

Pandya PR, RS Gupta, PM Talpada, GR Patel and MC Desai, 2005. Effect of complete feeds based on wheat straw and Prosopis julifora pods on growth and reproductive performance of growing crossbred heifers. Ind. J. Anim. Sci., 75: 56-59.

Rao KA, R Kishorek and DS Kumar, 2014. Growth performances ram lambs fed different roughage based total mixed rations. Indian j. Anim. Nutr., 2:121-127.

Reid RL, JP Hogan and PK Briggs, 1957. The effect of diet on individual volatile fatty acids in the rumen of sheep, with particular reference to the effect of low rumen $\mathrm{pH}$ and adaptation on high starch diets. Aust. J. Agr. Res., 8: 691-710. 
Sehgal JP and P Jha, 2008. Efficient utilization of fibrous crop residues in ruminants. In Proceedings of the national seminar on emerging opportunities for commercialization in dairying, NDRI, Karnal, India. pp. 73 82.

Sharma D, DP Tiwari and BC Mondal, 2010. Performance of crossbred female calves fed complete ration as mash or block vis-a-vis conventional ration. Indian J. Anim. Sci., 80: 556-560.

Shojaeian K and SS Thakur, 2007. Effect of exogenous fibrolytic enzymes supplementation to substrates containing different roughage: concentrate ratios on in vitro rumen fermentation, DM and NDF degradability. Indian J. Dairy Sci., 60: 94-101.

SPSS version 17.0, 2008. Statistical packages for Social Sciences, Version 17.0, SPSS Inc., Illinois, USA.

Van Soest PJ, JB Robertson and BA Lewisp, 1991. Methods for dietary fiber, neutral detergent fiber, and nonstarch polysaccharides in relation to animal nutrition. J. Dairy Sci., 74:3583-3597.

Venkanna P, MR Reddy and GVN Reddy, 1997. Rumen fermentation pattern on complete diets based on dry mixed grass or cotton seed hulls in cross bred bulls. Indian J. Anim. Nutr., 14: 245-249.

Verma AK, UR Mehra, RS Dass and A Singh, 1996. Nutrient utilization by Murrah buffaloes (Bubalus bubalis) from compressed complete feed blocks. Anim. Feed Sci. Technol., 59: 255-263.

Walli TK, 2015. Straw based densified TMR block technology: an alternative approach to overcome green fodder shortage for ruminants.

Williams VJ and KR Christian, 1959. Concentrations of end products and morphological types of rumen bacteria in silage fed sheep. New Zealand J. Agr. Res., 2:387-393.

White SL, JA Bertrand, MR Wade, SP Washburn, JT Green and TC Jenkins, 2001. Comparison of fatty acid content of milk from jersey and Holstein cows consuming pasture or a total mixed ration. J. Dairy Sci., 84: $2295-2301$. 